\title{
地表および地下流に対する
}

\section{擬似 3 次元洪水流出モテル \\ QUASI-THREE DIMENSIONAL FLOOD RUNOFF MODEL ON SURFACE AND SUBSURFACE FLOWS}

\author{
琴浦 毅 ${ }^{1} \cdot$ 真野 明 $^{2}$ \\ Tsuyoshi KOTOURA and Akira MANO
}

${ }^{1}$ 学生員 東北大学大学院工学研究科修士課程 (广980-8579 宮城県仙台市青葉区青葉 06)
${ }^{2}$ 正会員 工博 東北大学教授 工学研究科付属災害制御研究センター (广980-8579 宮城県仙台市青葉区青葉 06)

\begin{abstract}
A simplified model for subsurface flow computation is developed by splitting the continuity equation on the flow into vertical and horizontal directions based on the evaluation that the major part of the lateral flow occurs in the saturated zone. This model is combined with the surface flow model on the channel network and applied to the Abukuma River watershed of $5,400 \mathrm{~km}^{2}$ area to reproduce the flood in 1998. Discharge hydrograph computed by this model shows good agreement with the observed one and remarkable improvement from the surface flow model.
\end{abstract}

Key Words: subsurface flow, continuity equation split, flood runoff, Abukuma River

\section{1. はじめに}

洪水流は土砂や栄養塩類などの各種物質の生産, 輸送の大部分をになうためにこれらの輸送を表現で きる分布型流出モデルの開発が望まれている. しか し, 従来の洪水流出モデルでは表面流だけを扱った モデルはあるが, 初期水分量や降雨形態により流出 率を降雨ごとに変えて計算をしなければならない欠 点があった. ある地点の流量のみを再現するならパ ラメーターを調整する事で十分目的が達せられるが， 洪水流に伴う物質輸送の評価を次の目標とする本研 究では, その基本となる洪水流の精度の良い予測の 実現のため, 降雨, 浸透, 地下流出などの諸物理過 程をできる限り忠実に取り込んだ分布型モデルの開 発を目指している.

地下水挙動を忠実に計算しようとすると計算が非 常に複雑になる．そこで鈴木ら ${ }^{1}$ (は時空間アイソパ ラメトリック要素を用いた有限要素法を用い, 地下 における飽和・不飽和領域境界が常に要素境界と一 致するように工夫した鉛直一次元計算法を提案した. 入江ら ${ }^{2)}$ はこの計算法と水平方向一次元飽和浸透流 計算を組み合わせた擬似二次元的計算法を提案し， 大型模型実験結果と比較してある程度良好な結果を 得ている. 地下水を考慮した分布型流出モデルの一
つとして TOPMODEL がある. TOPMODEL は物 理的基礎と計算の簡便性を有し，流域内において土 猿一地形指数が等しい地点では同じ流出特性を持つ という水文類似性に基づいて，流域を土壌一地形指 数により分割し，各分割流域毎に流出計算を行う集 中型的要素を含んでいた.敖ら けるモデルのパラメーターの空間分布が考慮できる ようにブロック型 TOPMODEL を用いた分布型流 出解析モデルを提案し，洪水流での再現も良好な結 果を得ている. また，その他に地下水を考慮した分 布型モデルとして TOPOG_IRM などが提案されて いる ${ }^{4)}$.このモデルは $10 \mathrm{~km}^{2}$ 程度の流域内の地形空 間分布，土袞特性，植生特性を用いる事で土㙵-植生 -大気間の動的相互関係を予測する擬似 3 次元的生 物物理基礎分布パラメーターモデルであり，土地利 用変化や植生の変化により生じる長期的な流域内水 収支応答を知るために用いた研究もある ${ }^{5}$.

非線形のために繰り返し計算が必要な入江らの手 法とは異なり, 本研究の計算法は地下水分量連続式 の本質を損なわずに分解し，一次元計算の合成によ り解を得るため繰り返し計算の必要がない。また， 飽和域における横流入量の分布勾配による地下水面 の変化を考慮する点で TOPOG_IRM とは異なるなど 新しい解法を提案した。 


\section{2. 地下水分モテル}

地下における座標軸を図-1のように地下水の水平 流下方向を $x$ 軸，鉛直上方に $z$ 軸をとり，地表面の 位置を $Z_{s}$, 地下水面の位置を $Z_{w}$, 不透水層の位置 を $Z_{b}$ とし, $(x, z)$ 方向の流速を $(u, w)$, 土㙵水分含 水率を $\theta$ で表すと土中の微小区間における水分連続 式は以下に示す(1)式になる。

$$
\frac{\partial \theta}{\partial t}=-\left(\frac{\partial u}{\partial x}+\frac{\partial w}{\partial z}\right)
$$

この式は 2 次元であるため直接解くと非常に複雑な 計算になるため,この連続式を満たすように簡略化 を行う必要がある. そこで本研究は $(1)$ 式を $(x, z)$ 方 向に分解してそれぞれの軸に対しての 1 次元計算を 行い, $z$ 方向の不飽和浸透計算の結果を $x$ 方向の計 算結果により補正する簡易的な方法の開発を試みた。

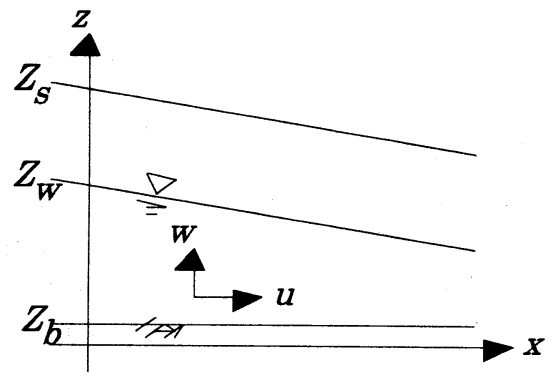

困-1＼cjkstart地下の座標系

\section{（1）地下水計算法概念}

(1)式の両辺を $Z_{b}$ から $Z_{s}$ まで積分すると，

$$
\int_{z_{b}}^{z_{s}} \frac{\partial \theta}{\partial t} d z=-\left(\int_{z_{b}}^{z_{s}} \frac{\partial u}{\partial x} d z+\int_{z_{b}}^{z_{s}} \frac{\partial w}{\partial z} d z\right)
$$

下層は不透水層の仮定から (2)式の右辺第 2 項は

$$
\int_{z_{b}}^{z_{s}} \frac{\partial w}{\partial z} d z=w_{s}-w_{b}=w_{s}\left(\because w_{b}=0\right)
$$

ここで， $w_{s}, w_{b}$ はそれぞれ地表面，最下層での 鉛直方向の水分移動速度である。

(2)式の左辺は, $Z_{b}, Z_{s}$ が時間によらないことか ら微分と積分の順序を変換でき，

$$
\int_{z_{b}}^{z_{s}} \frac{\partial \theta}{\partial t} d z=\frac{\partial}{\partial t} \int_{z_{b}}^{z_{s}} \theta d z=\frac{\partial \Theta}{\partial t}
$$

ここで $\Theta \equiv \int_{z_{b}}^{z_{s}} \theta d z \quad$ は単位面積の底面をもつ 浸透層柱に含まれる全水分量体積を表す。

(2)式の右辺第 1 項は積分範囲が $x$ の関数なので 次のライプニッツの公式(5)式を使い(6)式を得る.

$$
\begin{gathered}
\frac{\partial}{\partial t} \int_{\alpha(t)}^{\beta(t)} f(z, t) d z=\int_{\alpha(t)}^{\beta(t)} \frac{\partial f}{\partial t} d z+f(\beta, t) \frac{\partial \beta}{\partial t}-f(\alpha, t) \frac{\partial \alpha}{\partial t}(5) \\
\int_{z_{b}}^{z_{s}} \frac{\partial u}{\partial x} d z=\frac{\partial}{\partial x} \int_{z_{b}}^{z_{s}} u d z-\frac{\partial z_{s}}{\partial x} u_{s}+\frac{\partial z_{b}}{\partial x} u_{b}
\end{gathered}
$$

ここで $\partial z_{s} / \partial x$ と $\partial z_{b} / \partial x$ は各地表面と不透水層 表面の $x$ 方向の勾配であるが小さいと仮定すれば,

$$
\int_{z_{b}}^{z_{s}} \frac{\partial u}{\partial x} d z=\frac{\partial}{\partial x} \int_{z_{b}}^{z_{s}} u d z=\frac{\partial Q_{g}}{\partial x}
$$

ここで, $Q_{g} \equiv \int_{z_{b}}^{z_{s}} u d z \approx \int_{z_{b}}^{z_{w}} u d z$ は側方浸透流量 であるが，不飽和層の側方流量は小さいと確認され ている ${ }^{2)}$ ので飽和層の中だけの量で近似する.

以上より(2)式は(8)式になり，簡略化された。

$$
\frac{\partial \Theta}{\partial t}=-\left(\frac{\partial Q_{g}}{\partial x}+w_{s}\right)
$$

ここで $w_{s}$ を表面での水の移動速度で分解すると，

$$
w_{s}=-i_{s} \downarrow+w_{e} \uparrow+w_{g} \uparrow
$$

$i_{s} \downarrow$ : 地表降雨浸透速度

$$
i_{s}=\left\{\begin{array}{lll}
i_{s \max } & r_{s}>i_{s \max } & r_{s} \quad: \text { 降雨強度 } \\
r_{s} & r_{x}<i_{s \max } & i_{s \max }: \text { 最大浸透速度 }
\end{array}\right.
$$

$w_{e} \uparrow:$ 地表蒸発速度

$w_{s} \uparrow:$ 地下水湧出速度

となるが洪水解析では他の項に比べると $w_{e} \uparrow$ は小 さいので無視することにする.

\section{a) 連绱式の分解}

鉛直方向の浸透のみを考え側方流動を無視した 時の $\theta$ を $\theta_{1}$ とし(1)式を分解すれば，

$$
\frac{\partial \theta_{1}}{\partial t} \equiv-\frac{\partial w}{\partial z} \quad \begin{cases}z=z_{b} & w=0 \\ z=z_{s} & w=w_{s}\end{cases}
$$

この(10)式の両辺を $Z_{b}$ から $Z_{s}$ まで積分すると,

$$
\frac{\partial \Theta_{1}}{\partial t}=-w_{s}
$$

ここで, $\Theta_{1}=\int_{z_{b}}^{z_{s}} \theta_{1} d z$ を定義した.

次に側方流動を考える（10)式を(1)式に代入して，

$$
\frac{\partial \theta}{\partial t}=-\frac{\partial u}{\partial x}+\frac{\partial \theta_{1}}{\partial t}
$$

を得る.この(12)式を整理すれば,

$$
\frac{\partial\left(\theta-\theta_{1}\right)}{\partial t}=-\frac{\partial u}{\partial x}
$$

ここで, $\theta_{2} \equiv \theta-\theta_{1}$ とすると, これは水平方向流動 で生じる水分の補正分になる. (13)式から，

$$
\frac{\partial \theta_{2}}{\partial t}=-\frac{\partial u}{\partial x}
$$

(14)式を $Z_{b}$ から $Z_{s}$ まで積分すると，

$$
\frac{\partial \Theta_{2}}{\partial t}=-\frac{\partial Q_{g}}{\partial x}
$$




$$
\text { ここで， } \quad \Theta_{2} \equiv \int_{z_{b}}^{z_{s}} \theta_{2} d z
$$

を定義する。

$\theta_{2}$ は側方の流入量, 流出量に変化があることによ って生じる水分変化分布で, しかも側方流動は飽和 浸透層内での流動なので, $\theta_{2}$ は地下水飽和面近くに おける変化である.つまり, 側方流動の変化により 生じる地下水面の変化を $\theta_{2}$ を用いて示す. $\theta$ は $\theta_{1}$ の 形を変えないで, $z$ 方向に $c_{g} \times d t$ だけ平行移動し ただけとする.このとき(16)式の積分量，つまり側 方流動の相違による水分変化量は図-2に示すように 考えられるため,

$$
\Theta_{2}=\int_{\theta_{\min }}^{\theta_{\max }} c_{g} \cdot \delta t d \theta=c_{g} \cdot \delta t\left(\theta_{\max }-\theta_{\min }\right)
$$

となり，(15)式に代入すると，

$$
c_{g}\left(\theta_{\max }-\theta_{\min }\right)=-\frac{\partial Q_{g}}{\partial x}
$$

が得られ,これから以下の式を得る.

$$
c_{g}=-\frac{1}{\theta_{\max }-\theta_{\min }} \frac{\partial Q_{g}}{\partial x}
$$

以上から $\partial Q_{g} / \partial x, \theta_{\max }-\theta_{\min }$ が分かれば $c_{g}$ を計 算でき，このとき，

$$
\theta_{2}=-\frac{\partial \theta_{1}}{\partial z} c_{g} \cdot \delta t
$$

が与えられ，

$$
\theta=\theta_{1}+\theta_{2}=\theta_{1}-\frac{\partial \theta_{1}}{\partial z} c_{g} \cdot \delta t
$$

この計算法で鉛直方向の計算を行えば，側方方向 の浸透により生じる水分量変化を比較的求めやすい $\partial Q_{g} / \partial x$ を用いて計算でき,繰り返し計算を用いな いで直接 $\theta$ を知ることができることから，地中水の 計算を簡略化できるものである。
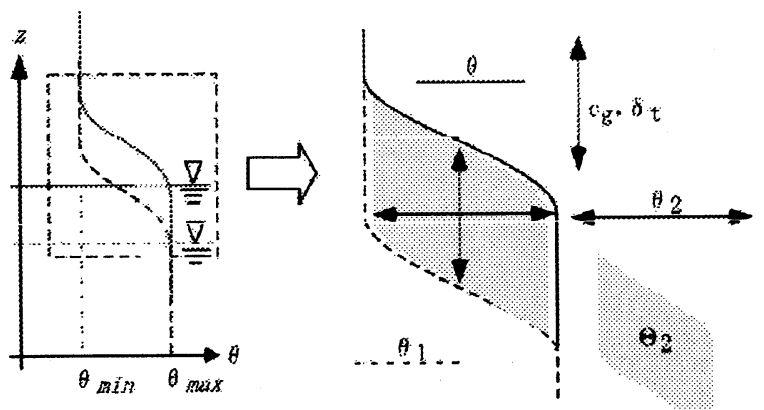

因-2 補正方法の概念図

\section{b) 哈直方向㖕算}

不飽和域で生じる不飽和鉛直浸透により変化す る水分量を先ほど定義したように $\theta_{1}$ とし, $\theta_{1}$ 変化の 計算を入江ら ${ }^{2)}$ にならい以下の 3 式(Richards の式, Brooks \& Corey の表示法, Cambell の表示法)を用
いて計算を行った。

$$
\begin{gathered}
\frac{\partial \theta_{1}}{\partial \psi} \frac{\partial \psi}{\partial t}=\frac{\partial}{\partial z}\left\{k_{z}(\psi)\left(\frac{\partial \psi}{\partial z}+1\right)\right\} \\
\frac{\partial \theta_{1}}{\partial \psi}=\left(\theta_{s}-\theta_{r}\right) \lambda \frac{\psi_{c r}^{\lambda}}{\psi^{\lambda+1}} \\
k_{z}(\psi)=k_{s o}\left(\frac{\psi_{c r}}{\psi}\right)^{\gamma}
\end{gathered}
$$

ここで, $\psi$ は圧力水頭, $k_{z}(\psi)$ は不飽和透水係数, $\theta_{s}$ は飽和体積含水率, $\theta_{r}$ は最小体積含水率, $k_{s o}$ は 飽和透水係数, $\psi_{c r}$ は限界圧力水頭, $\gamma, \lambda$ は定数 である。

\section{c) 水平方向の㖕算}

水平方向は飽和域でのみ浸透が起こると考えるた めダルシー則(25)を用いて求める.

$$
Q_{g}=-k_{s o} h i
$$

ここで, $Q_{g}$ は側方浸透流量, $k_{s o}$ は飽和透水係数, $h$ は飽和層の厚さ, $i$ は動水勾配である.

\section{d) 地下水面位置の決定}

b)の計算により不飽和鉛直浸透を計算し,鉛直方向 の水分分布が得る. 次にその水分分布により決定さ れる地下飽和層の厚さを用いて c)により得られる水 平飽和浸透の流出量を求める. 全メッシュの流出量 を求め, それを用い全メッシュの流入量を求める. 流入流出量の差により生じる水分分布の変化(21)式 により計算すれば最終的な水分分布を得る．その水 分分布より地下水面の位置を決定する. 図-3 はこの 計算のフローチャートを示したものであり，この計 算法により 2 次元地下水挙動の計算を簡略化して行 うことができる.

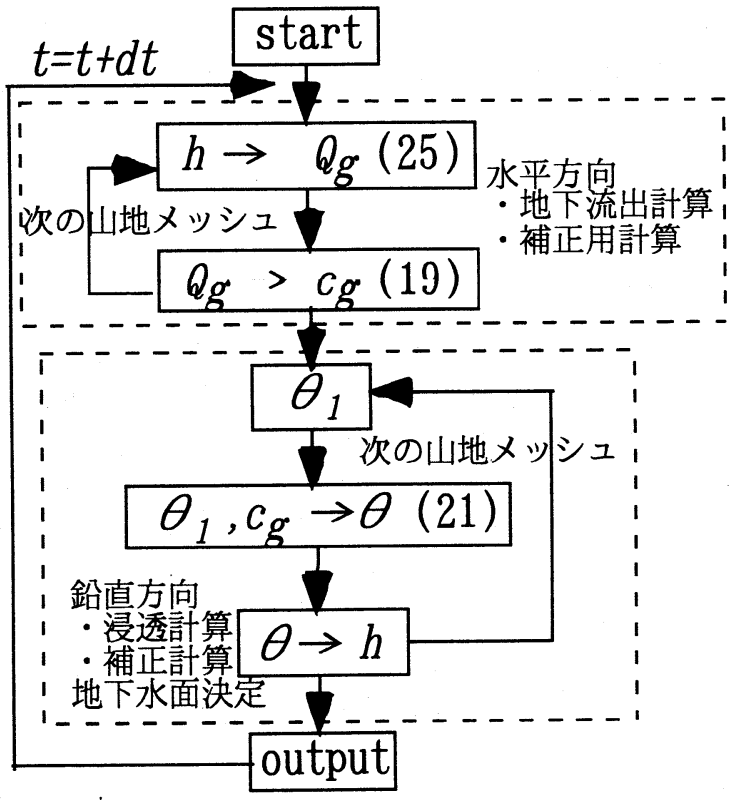

图-3 地下水分計算のフローチャート 


\section{(2) 新開発計筷法の梌证}

この新しい計算法の妥当性を検証するために建設 省土木研究所で行われた大型模型実験に適用した。 この計算で用いた土培特性パラメーターは実験時に 測定された実験值を用いて計算を行い，降雨条件の 有無に関わらず計算值結果は良好な結果を示した ${ }^{6)}$. 計算用の土䗙特性パラメーターを用いるのではなく 実際に測定された物理的なパラメーターを用いて計 算し良好な結果を得たことから，この計算方法が物 理的現象を再現できていると考えられ，また降雨の 有無にかかわらず良好な結果が得られていることか ら実現象においての実用性の可能性が高いと考えら れ，この計算法を阿武隈川流域の分布型モデルに適 用した。

\section{3. 阿武隈川流域への道用}

\section{(1) 壾算乘件}

阿武隈川流域(図-4:流域面積 : $5,400 \mathrm{~km}^{2}$ )を国土数 值情報により $500 \mathrm{~m} \times 500 \mathrm{~m}$ メッシュサイズで分割 し，各メッシュの標高值を用いて落水線法により擬 河道網を作成した. 張ら ${ }^{n}$ の導入した位数を用い， 位数 6 以上を河道，それ以外を斜面と分類した. 斜 面の中でも阿武隈川流域の山地面積 $3983 \mathrm{~km}^{2}$ に最 も近づくように 1 メッシュ内の土地利用区分の森林 割合が $30 \%$ 以上となるメッシュを山地斜面と考え, それ以外のメッシュを平地斜面とした。また，降雨 の地下への浸透は山地斜面でのみで起こると仮定し， 山地斜面は深さ方向に 20 のメッシュに分割して計 算を行った. 今回の計算では地下の浸透, 貯留を考 慮するために有効降雨ではなく実降雨量を用いた。 また, 洪水時における蒸発散は無視した. 初期土堛 水分は, 鉛直方向に $\Phi=\psi+z=0(\Phi$ : ピエゾ水 頭, $\psi$ : 圧力水頭, $z$ : 高度水頭)を満たすように 分布させた。

こうして今囘の新しい計算方法を組み込んだ㳻水 分布型流出解析モデルを 1998 年 8 月下旬の出水に 適用した。

\section{（2）計算方法}

\section{a) 表面流}

表面流の計算は河道流や表面流は八代ら $\left.{ }^{8}\right)$ になら い kinematic wave 法を用いて計算を行い，擬河道 網を通じて河口まで追跡計算する．任意断面形状の 流路における洪水移動速度を表す Kleitz \& Seddon の式を利用すると支配方程式は次式になる.

$$
\begin{array}{r}
\frac{1}{w} \frac{\partial Q}{\partial t}+\frac{\partial Q}{\partial x}=r B_{s l} \\
w=\frac{Q}{A}\left(\frac{5}{3}-\frac{2}{3} \frac{A}{B^{2}} \frac{\partial B}{\partial y}\right)
\end{array}
$$

ここで, $w$ は洪水の移動速度, $Q$ は流量, $t$ は時間,

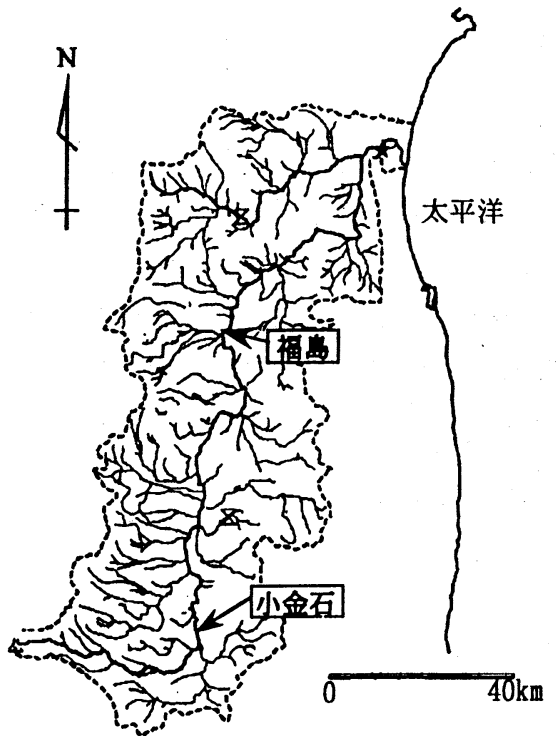

困-4 流域図と流量観測所の位置

$x$ は流下方向の距離, $y$ は水深方向の距離, $A$ は流 域断面積, $r$ は降雨量, $B$ は水面幅, $B_{s l}$ は降雨を 与える幅である. 等流を仮定すると， $A, B$ はマ二 ングの公式を用いて $Q$ を使って表現できる.この式 を差分化して流出計算を行う.

マニングの公式で用いられる粗度係数は八代ら ${ }^{8)}$ の表面流のみを考慮したモデルとの比較を行うため に同じ值(表-1)を用いた。

\section{b) 地下水尌算}

今回開発した計算方法に用いる土㖶パラメーター は小田ら ${ }^{99}$ の現地調査により得られた実測值などに より決定し,これらのパラメーターは流域全体で一 様とした(表-1). また，地下水流下方向は斜面流下 方向に等しく地下水面勾配は地表面勾配に等しいと してダルシー則を適用し, 各メッシュへの流入流量 流出流量の差とそのメッシュにおける鉛直浸透計算 結果を用いて鈴直方向の水分分布を決定し，各メッ シュこととに地下水面を決定した。

\begin{tabular}{|c|c|c|c|}
\hline パラメーター分類 & パラメーター名 & $\begin{array}{c}\text { 旧モデル } \\
\text { (表面流のみ) }\end{array}$ & $\begin{array}{c}\text { 新モデル } \\
\text { (地下水含む) }\end{array}$ \\
\hline 降雨パラメーター & 流出率 & 0.73 & - \\
\hline \multirow[t]{2}{*}{ 表面流パラメーター } & 斜面粗度 & 0.1 & 0.1 \\
\hline & 河道粗度 & 0.04 & 0.04 \\
\hline \multirow[t]{7}{*}{ 地下水パラメーター } & 浸透層厚さ(m) & - & 1.5 \\
\hline & $K s o(\mathrm{~cm} / \mathrm{sec})$ & - & 2.0E-02 \\
\hline & $\Psi_{c r}(\mathrm{~m})$ & - & 0.4 \\
\hline & $\theta s$ & - & 0.6 \\
\hline & $\theta r$ & - & 0.3 \\
\hline & $\gamma$ & - & 2.8 \\
\hline & $\mathrm{z}$ 方向メッシュ数 & - & 20 \\
\hline
\end{tabular}

袁-1 計算パラメーター 


\section{4. 結果の比較}

\section{(1) 新モデルと旧モデルとの比較}

計算值と実測值との比較を福島と小金石において 比較する．流域内におけるこれらの観測所の位置を 図-4に示し, ハイドログラフの比較を図-5 に示す. 図-5において縱軸は 1 時間あたりの流量 $Q\left(\mathrm{~m}^{3} / \mathrm{s}\right)$, 横軸は時間 $t(\mathrm{hr})$, グラフの太い実線は観測値, 細線 は計算值を示す.また，モデルの洪水ハイドログラ フの再現性を検討するための評価関数として以下の NASH 効率を用いた。

$\left.\left.e=\left[1-\left\{\sum_{t=1}^{N}\left(Q_{s m}(t)-Q_{o b}(t)\right)^{p} / \sum_{t=1}^{N} Q_{o b}(t)-\bar{Q}_{o b}\right)\right\}\right] \times 100\right)$

ここで， $t$ は時間ステップ, $N$ は総時間ステップ, $Q_{o b}(t), Q_{s m}(t)$ はそれぞれ時間ステップ $t$ における 観測値, 計算值, $\bar{Q}_{o b}$ は観測值の時間平均值である. これにより求めた福島，小金石流量観測所における NASH 効率の比較を表-2 示す.

図-5からモデルにより降雨に対する応答が異なっ ているのが分かる.これは全ての降雨が直接流量に 寄与せず，地中に浸透し残留する降雨成分があるた めに降雨変化が直接流量変化につながらないと言っ た実現象を，降雨の地中への浸透を考慮できる新モ デルが実現象に近い計算が行った結果である.

また，比較的早い変化を示す表面流に比べると中 間流地下水流量の変化は遅いため, 表面流が減少し た後においても持続的に地下水流は流出を続ける. その結果，ハイドログラフの谷部では地下水流出流 量が確保されるし，ピーク後の減少も表面流が早期 に減少した後に地下水がゆっくりと減少するためハ イドログラフの減少は非常になだらかなになる．新 モデルの精度向上はこの現象も計算を行えている結 果であると考えられる。

これらより新モデルは今回開発した鉛直方向と水 平方向計算は簡易的な計算法であるが効果的に計算 され，精度の向上が見られたと考えられ，表-2に示 すように数值的な観点から精度の向上も確認された。

また，図-7 は縦軸に NASH 効率(\%), 横軸に河口 からの距離をとり, 流域内に存在する観測所におけ る NASH 効率を示している.これから新モデルの計 算精度は旧モデルに比べて流域全体において向上し ていることが確認され，また，新モデルは流域全体 で良い精度を保持していることが確認された。

表-2 新旧モデルの NASH 効率の比較(福島，小金石）

\begin{tabular}{|c|c|c|}
\hline & 福島 & 小金石 \\
\hline 旧モデルのNASH効率(\%) & 44.13 & 72.39 \\
\hline 新モデルのNASH効率(\%) & 99.85 & 86.2 \\
\hline 河ロからの距離( $(\mathrm{km})$ & 77 & 165 \\
\hline 観測所での流域面積 $\left(\mathrm{km}^{2}\right)$ & 3171.9 & 524.4 \\
\hline
\end{tabular}
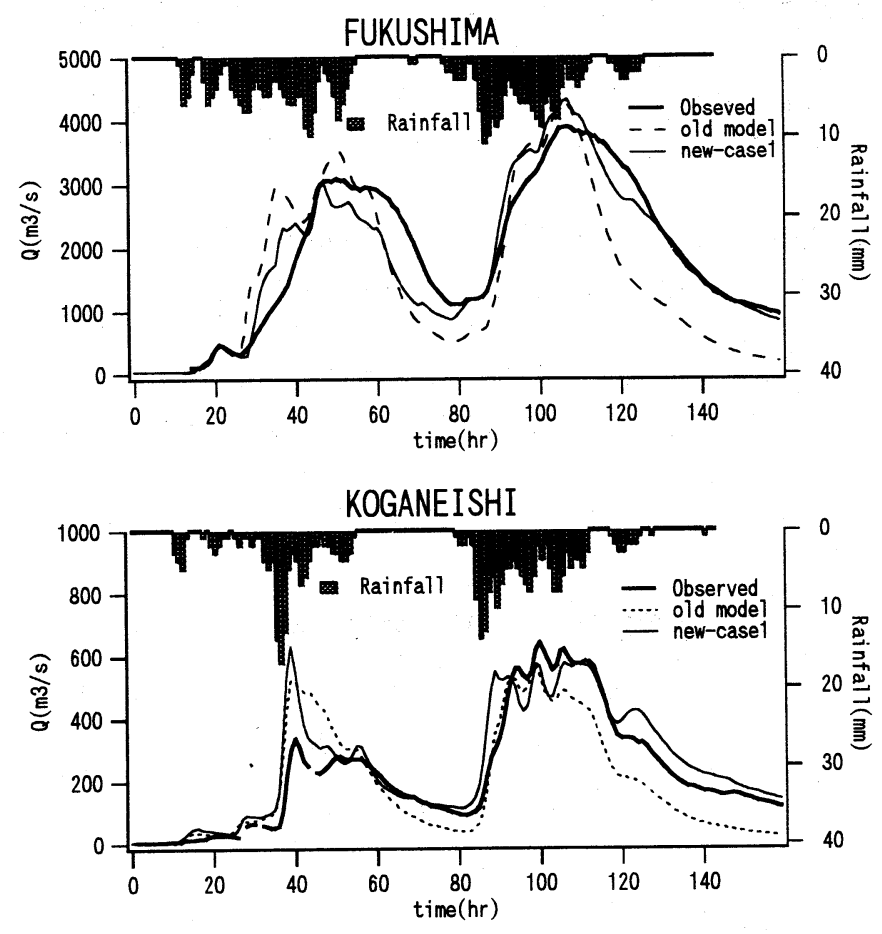

図-5実測值と新旧モデルとの比較(福島，小金石)

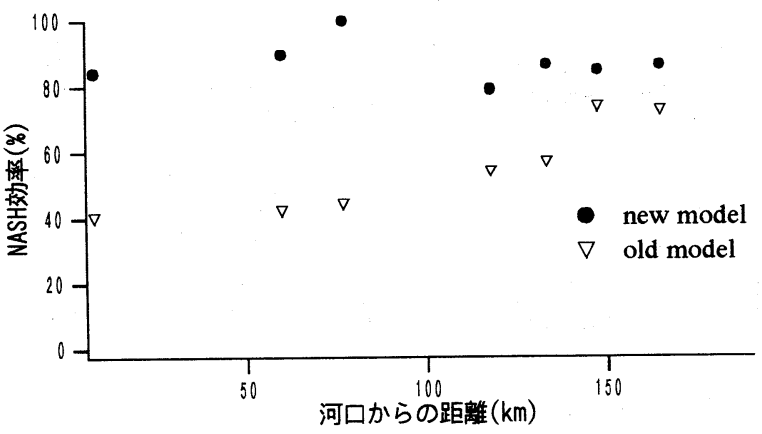

困-6 新旧モデルの流域内での NASH 効率の比較

\section{(2) 新モデルにおける各パラメーターの効果}

流出計算には表-1 に示すようなバラメーターを用 いるがそれぞれのパラメーターが計算結果に及ぼす 影響を知るために, 表-3のように 2 個のパラメータ 一を変化させて $3 つ の$ case を設定して行った計算を 福島, 小金石の各流量観測所についての結果比較を 図-7に示す。

袁-3 比較検討のパラメーター

\begin{tabular}{|c|c|c|c|}
\hline & case1 & case2 & case3 \\
\hline 浸透層厚さ(m) & 1.5 & 2.0 & 1.5 \\
\hline Kso(cm/sec) & $2.0 \mathrm{E}-02$ & $2.0 \mathrm{E}-02$ & $5.0 \mathrm{E}-03$ \\
\hline
\end{tabular}

a) 浸远層序さの效果(case1,case2)

実測值と比べると降雨初期は case 1 の流量が多い が，その後は case2 の流量が多くなっている. 厚い 浸透層は多くの水を浸透させるのが可能ため, 降雨 初期では地下に浸透する成分が多く, 流出に寄与す る成分は少ない。しかし，浸透層が飽和した後は飽 
和層が厚いほど地下水流量が増大し，また飽和状態 のために降雨は地下へ浸透できずにそのまま表面流 として流出し, 表面流と地下水流の合計としては浸 透層の厚い方が大きな值を示すため，この比較にお いても生じたと考えられる。

\section{b) 远水保数の变化に対する比較(case1,case3)}

グラフ上では透水係数が低い case3 の流量が低い 值を示している.これは地表面浸透速度が降雨強度 より早いために降雨は地中へ浸透するが，透水係数 が低いため地下水移動は遅く，地下水流量が小さい ために，表面流と地下水流の合計であるハイドログ ラフは小さい值を示していると考えられる.
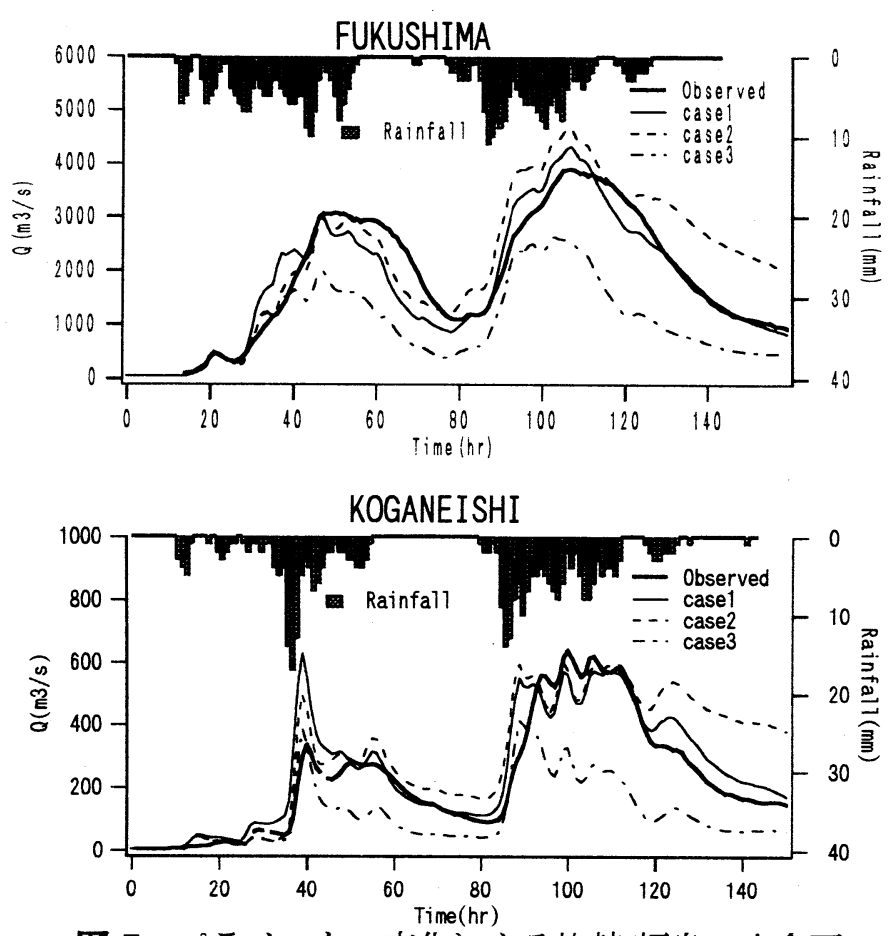

図-7 パラメーター変化による比較(福島，小金石)

\section{5. 結論}

複雑な地下水挙動を物理的な根拠に基づき簡略 化して開発した今回の計算法は，収束するまで繰り 返し計算を行う入江ら ${ }^{2)}$ の手法に比べると簡単であ るにもかかわらず，大型模型実験に適用した結果， 精度に差異は認められなかったため，今回開発した 計算法の優位性が示せたと言える。

また，今回の計算法を阿武隈川流域の分布型洪水 流出モデルに適用し, 精度の向上と妥当性を確認で きたことは，地下水を考慮に入れた洪水流分布型モ デルの新しい計算法の可能性を提案できたと言える. この分布モデルは TOPMODEL のような集中型性 質を持つのではなく, 各メッシュごとの勾配，浸透， 流出, 飽和度を用いて計算している点, 比較的狭い 領域で長期的な水文的応答を見る TOPOG_IRM MODEL と比較すると，阿武隈川流域という大流域
を扱っている点, 洪水という短期間流出精度良く再 現できた点など他の地下水を考慮した分布型モデル と比較すると，物理的に基づいた簡易地下水計算を 含んだ今回のモデルの洪水時流出モデルとしての価 值は非常に高いものであると言える.

今後, 今回開発した分布型洪水流出モデルの理解 を深め, さらに発展させることで土砂移動を始めと する物質輸送モデルへの発展が期待される.

辢辞 : 本研究を行うにあたり貴重な流量デー夕を頂 いた建設省仙台工事事務所，福島工事事務所，福島 県土木事務所，降雨のデータを頂いた気象庁，JR 東日本, 日本道路公団, 東北電力に謝意を表します.

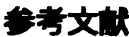

1) 鈴木伴征, 入江光輝, 石川忠晴 : 鉛直不飽和浸透流計算 における飽和域・不飽和域の接合に関する数学的処理に ついて，土木学会論文集，593，pp.11-19，1998.

2) 入江光輝, 鈴木伴征, 石川忠晴 : 水平飽和浸透と鉛直不 飽和浸透を可変境界で接合した疑似二次元的浸透流計 算について, 水工学論文集, 第 43 巻, pp.181-186, 1999 . 3)敖 天其, 石平 博, 竹内 邦良 : ブロック型 TOPMODEL 及びM-C 追跡法による分布型流出解析モ デル，水工学論文集，第 43 巻，pp.7-12，1999.

4) Warrick R.Dawes,Lu Zhang,TomJ.Hatton,Peter H. Reece,G.T,H Beale, and I.Packer : Evaluation of a distributed parameter ecohydrological model(TOPOG IRM) on a small cropping rotation catchment,Jounal of Hydrology,191,pp.64$86,1997$.

5) L.Zhang,W.R.Dawes,T.j.hatton,P.H.Reece,G.T.H.Beal $\mathrm{e}$, and I.Packer : Estimation of soil moisture and groundwater recharge using the TOPOG IRM model ,WATER RESOURCES RESEARCH VOL.35,NO.1,pp.149-161,1999.

6) 琴浦毅・真野明 : 分伂型地下水流出モデルの開発, 東北 地域災害科学研究, 第 36 巻, pp.177-pp.182, 2000.

7) 張 旭紅, 首藤 伸夫, 石川 忠晴 : 国土数值情報を用 いる流出および濁質発生量の解析，水工学論文集第 36 巻, pp.665-670, 1992.

8) 八代義信・真野 明:河道特性を考虑した阿武隈川流域 の流出解析，土木学会第 51 回年次学術講演会講演概要 集, pp.704-705，1996.

9) 小田匡寛，鈴木輝一，川本健 : 1998 年南東北・北関東 の集中豪雨による土砂災害の実態調查，1998 年南東 北・北関東の集中豪雨災害に関する調査研究，平成 10 年度科学研究補助金(基盤研究(B)(1))研究成果報告書, pp.163-181, 1999.

(2000.10.2 受付) 